\title{
UCRL-JRNL-227120
}

LAW RENCE LIVERMORE N A T IO N A L LABORATORY
Online Aerosol Mass Spectrometry of Single Micrometer-Sized Particles Containing Poly(ethylene glycol)

M. J. Bogan, E. Patton, A. Srivastava, S. Martin, D. Fergenson, P. Steele, H. Tobias, E. Gard, M. Frank

January 8, 2007

Rapid Communications in Mass Spectrometry 
This document was prepared as an account of work sponsored by an agency of the United States Government. Neither the United States Government nor the University of California nor any of their employees, makes any warranty, express or implied, or assumes any legal liability or responsibility for the accuracy, completeness, or usefulness of any information, apparatus, product, or process disclosed, or represents that its use would not infringe privately owned rights. Reference herein to any specific commercial product, process, or service by trade name, trademark, manufacturer, or otherwise, does not necessarily constitute or imply its endorsement, recommendation, or favoring by the United States Government or the University of California. The views and opinions of authors expressed herein do not necessarily state or reflect those of the United States Government or the University of California, and shall not be used for advertising or product endorsement purposes. 


\section{Online Aerosol Mass Spectrometry of Single Micrometer- Sized Particles Containing Poly(ethylene glycol)}

Michael J. Bogan, ${ }^{1}$ Elizabeth Patton, ${ }^{2}$ Abneesh Srivastava, ${ }^{1}$ Sue Martin, ${ }^{1}$ David P. Fergenson, ${ }^{1}$ Paul T. Steele, ${ }^{1}$ Herbert J. Tobias, ${ }^{1}$ Eric E. Gard, ${ }^{1}$ Matthias Frank ${ }^{1 *}$

${ }^{1}$ Lawrence Livermore National Laboratory, Livermore, California, USA

${ }^{2}$ University of Maryland, College Park, Maryland, USA

*Corresponding author. Mailing address: Lawrence Livermore National Laboratory, 7000 East Ave L-211, Livermore, CA, 94550, USA. Phone: (925) 423-5068. Fax: (925) 424-2778. E-mail: frank1@1lnl.gov 


\section{ABSTRACT}

Analysis of poly(ethylene glycol)(PEG)-containing particles by online single particle aerosol mass spectrometers equipped with laser desorption ionization (LDI) is reported. We demonstrate that PEG-containing particles are useful in the development of aerosol mass spectrometers because of their ease of preparation, low cost, and inherently recognizable mass spectra. Solutions containing millimolar quantities of PEGs were nebulized and, after drying, the resultant micrometer-sized PEG containing particles were sampled. LDI $(266 \mathrm{~nm})$ of particles containing $\mathrm{NaCl}$ and PEG molecules of average molecular weight $<500$ generated mass spectra reminiscent of mass spectra of PEG collected by other MS schemes including the characteristic distribution of positive ions $\left(\mathrm{Na}^{+}\right.$adducts) separated by the $44 \mathrm{Da}$ of the ethylene oxide units separating each degree of polymerization. PEGs of average molecular weight $>500$ were detected from particles that also contained the tripeptide tyrosinetyrosine-tyrosine or 2,5-dihydroxybenzoic acid, which were added to nebulized solutions to act as matrices to assist LDI using pulsed $266 \mathrm{~nm}$ and $355 \mathrm{~nm}$ lasers, respectively. Experiments were performed on two aerosol mass spectrometers, one reflectron and one linear, that each utilize two time-of-flight mass analyzers to detect positive and negative ions created from a single particle. PEG-containing particles are currently being employed in the optimization of our bioaerosol mass spectrometers for the application of measurements of complex biological samples, including human effluents, and we recommend that the same strategies will be of great utility to the development of any online aerosol LDI mass spectrometer platform.

Aerosol mass spectrometry has applications from the analysis of environmental particles ${ }^{1-12}$ to rapid detection of airborne microorganisms ${ }^{13-21}$ and is 
well-represented by a suite of different particle sampling, ionization, and mass spectrometer strategies. 5, 7, 22 Recently, aerosol mass spectrometers implementing matrix-assisted laser desorption/ionization (MALDI), more common to biomolecule analyses for proteomic applications, have facilitated the detection of larger molecular weight labile molecules such as peptides and proteins contained in aerosol particles. Aerosol particles containing MALDI matrix are created through an online coating process $^{15,23}$ or by nebulizing a solution containing the analyte and a MALDI matrix. $^{24-28}$ The latter approach has proven highly sensitive, as evidenced by the detection of $\sim 14$ zeptomole of a $1 \mathrm{kDa}$ peptide in a single micrometer-sized aerosol particle. $^{29}$ The high sensitivity attained by this methodology and previous approaches utilizing micrometer-sized MALDI samples ${ }^{30-35}$ suggests MALDI mass spectrometers designed to handle smaller quantities of sample material could result in further gains in sensitivity for biomolecules. Coupled with sample preparation methods capable of creating and manipulating small volumes of sample material, such technology holds great potential for analysis of precious biological sample materials.

We are developing real-time single particle bioaerosol mass spectrometry (BAMS) instruments for applications in national security including rapid airborne microorganism detection, health and environmental monitoring. ${ }^{16-19,21,29,36-38}$ Current instruments are equipped with combinations of multiple particle tracking lasers and separate TOF mass analyzers (either two linear or two reflectron) for detection of positive and negative polarity ions created from each single particle. Single particles drawn into the system are sequentially classified based on their aerodynamic diameter and the positive or negative ions detected (primarily in the range $\mathrm{m} / \mathrm{z}=350$ ) have proven very successful for the discrimination of single airborne bacteria from complex environmental aerosol samples. ${ }^{18}$ We are now exploring the application of 
BAMS to the analysis of complex biological samples such as lung surfactant. ${ }^{39}$ In this application, it is desirable to achieve high resolution and mass accuracy at $\mathrm{m} / \mathrm{z}>350$ in order to detect ion signals from intact biomolecules such as lipids, peptides and proteins. Compared to fixed-target MALDI-MS instruments where additional sample is typically available by just moving to a new spot, online aerosol instruments suffer from the limitation of having just a single shot to hit a given particle. Even if the particle is "hit" there is such a small amount of material in the micrometer-sized particle that it is often difficult to detect the low absolute number of higher molecular weight ions produced. Thus, to facilitate mass spectrometer optimization for this application, standard particles that generate easily recognizable mass spectra containing ions with $\mathrm{m} / \mathrm{z}>350$ and provide satisfactory particle-to-particle reproducibility are required. Here, solutions containing variations of a polymer commonly employed in the development and calibration of many other types of mass spectrometers, poly(ethylene glycol) (PEG), ${ }^{40-46}$ were studied on two aerosol mass spectrometers. The utility of PEG for the development of aerosol mass spectrometers is demonstrated with a flexible strategy to create PEG-containing particles that produce negative ions to $\mathrm{m} / \mathrm{z}=1500$ and positive ions to $\mathrm{m} / \mathrm{z}=4500$. It is envisioned that these PEG-containing particles will be useful in the development of any LDIequipped aerosol mass spectrometers because of their ease of preparation, low cost, and inherently recognizable mass spectra.

\section{EXPERIMENTAL}

\section{Aerosol Generation}

Poly(ethylene glycol) average molecular weight 200, 400, 1000, and 2000, 3350, (i.e., PEG200) Poly(ethylene glycol) 4-nonylphenyl 3-sulfopropyl ether 
potassium salt (PEG(-)), tyrosine-tyrosine-tyrosine (YYY) and 2,5-dihydroxybenzoic acid (DHB) were purchased from Sigma-Aldrich (St. Louis, MO) and used without further purification. The following stock solutions were prepared in $\mathrm{H}_{2} \mathrm{O}: 2 \mathrm{mM}$ PEG200 and 400; 10 mM PEG1000, 2000, 3350 and PEG(-); 5 mM YYY; $10 \mathrm{mM}$ $\mathrm{NaCl} ; 10 \mathrm{mM} \mathrm{KCl}$ and $200 \mathrm{mM}$ DHB. Various combinations of the stock solutions were prepared by dilution with $\mathrm{H}_{2} \mathrm{O}$. To introduce samples to the mass spectrometer, solutions are typically aerosolized in a stream of nitrogen gas (flow rate of $\sim 1.5$ L/min) using a low volume $(2-5 \mathrm{ml})$ disposable nebulizer (Salter Labs, Arvin, CA). The aerosol droplets are dried through a silica desiccant column resulting in particles with average aerodynamic diameter $1.2 \mu \mathrm{m}(\sim 0.8-4 \mu \mathrm{m}$ diameter range) that contain primarily PEG and any nonvolatile components present in the original solution. For example, particles prepared from an equimolar PEG400 and $\mathrm{NaCl}$ solution were $50 \%$ PEG by mole fraction after the water evaporated. PEG-containing particles are sampled into the mass spectrometers through copper or conductive silicone tubing. Aerosol particle aerodynamic diameter is determined from online measurement of terminal velocity calibrated with standard polystyrene latex particles. ${ }^{29}$

\section{Mass Spectrometry}

Experiments were performed on two single particle aerosol MS instruments, (1) a reflectron TOFMS (ATOFMS 3800, TSI, MN) modified to have a flat-topped beam $^{36}$ from a $266 \mathrm{~nm} \mathrm{Nd:YAG} \mathrm{laser} \mathrm{(Ultra,} \mathrm{Big} \mathrm{Sky} \mathrm{Laser,} \mathrm{MT)} \mathrm{and} \mathrm{(2)} \mathrm{a} \mathrm{linear}$ TOFMS. ${ }^{29,}{ }^{37}$ For both instruments, aerosolized particles are passed through three successive instrument regions. In the first, they are sampled into the instrument through a nozzle and skimmed into a collimated beam under vacuum. In the second, they are tracked by two (instrument 1) or three (instrument 2) scattering lasers to establish terminal velocity and aerodynamic diameter. This velocity is used to 
calculate the trigger time of a $266 \mathrm{~nm} \mathrm{Nd:YAG} \mathrm{laser} \mathrm{(instrument} \mathrm{1)} \mathrm{or} \mathrm{a} 355 \mathrm{~nm}$ Nd:YAG laser (instrument 2), fired at each tracked particle as it passes into the $\sim 400$ $\mu \mathrm{m}$ laser spot in the third region, the TOFMS. Positive and negative ions created in the ionization region are separately detected on two TOF mass analyzers, resulting in two mass spectra recorded for each particle. Spectra were acquired at several laser pulse energies (from $0.2 \mathrm{~mJ}$ per pulse to $1.0 \mathrm{~mJ}$ per pulse). All mass spectra are of positive ions unless otherwise noted. Our $\mathrm{m} / \mathrm{z}$ calibrations were based on the formula $(\mathrm{m} / \mathrm{z})^{1 / 2}=\mathrm{a}(\mathrm{TOF})+\mathrm{b}$ and used three peaks. The data in Figure 3 was smoothed by a boxcar average of 5 .

\section{RESULTS AND DISCUSSION}

\section{Mass Spectra of PEG-containing Particles}

Although poly(ethylene glycol) (PEG) has been studied using many types of mass spectrometers, this is the first report of its use in single particle aerosol mass spectrometers. Averaged mass spectra collected of the positive ions produced by laser desorption ionization of many single PEG-containing particles were consistent with mass spectra of PEGs collected by other ionization and mass spectrometry schemes, 40-46 including average mass spectra from the coupling of online aerosol MALDI-MS with gel permeation chromatography of PEGs. ${ }^{47}$ In the case of particles containing PEG400, the adduct ions formed were dependent on the alkali metal ions present in the starting solution nebulized to create the particles (Figure 1). The spectra exhibited the characteristic distribution of ions associated with the different number of monomer units of the collection of molecules in the PEG sample that result from the varied degrees of polymerization $(n)$ of the polymer. Single particle mass spectra (Figure 1D) usually contain ions for all values of $n$ and ion abundance generally correlates with that observed in the averaged spectra. Occasionally no signal for some 
values of $n$ is detected. For example, no signal for the ion $[\mathrm{PEG} 12+\mathrm{Na}]^{+}$is detected in the single particle spectrum in Figure 1D.

Comparison of spectra from particles containing $\mathrm{NaCl}$ (Figure 1A) with those containing $\mathrm{KCl}$ (Figure 1B) reveal the expected $16 \mathrm{~m} / \mathrm{z}$ unit shift in the ion distribution due to the substitution of $\mathrm{Na}^{+}$by $\mathrm{K}^{+}$as the adduct ion. When particles are prepared from solutions containing equimolar $\mathrm{Na}^{+}, \mathrm{K}^{+}$and PEG400, the $\mathrm{Na}^{+}$adducts are the most intense in the LDI mass spectrum (Figure 1C). By comparison, MALDIMS of PEG solutions containing DHB matrix and equimolar $\mathrm{Na}^{+}$and $\mathrm{K}^{+}$show that the PEG has a higher selectivity for $\mathrm{K}^{+48}$ It is possible that further study of the ions created from single particle MALDI versus LDI using this polyether-alkali metal ion adduct system may provide insights into the fundamentals of ionization ${ }^{49-52}$ of single particles relative to samples prepared by conventional methods.

The $266 \mathrm{~nm}$ LDI of particles created from a solution containing PEG2000 did not produce any detectable ions in the mass spectrum in the $\mathrm{m} / \mathrm{z}$ range of $1500-2500$ (Figure 2A). Ions detected from particles containing PEG 1000 had signal-to-noise ratios comparable to higher values of $n$ in the PEG 400 distribution, i.e. $n=13-15$ and became negligible by $\mathrm{m} / \mathrm{z} \sim 1200$. This suggests that LDI of PEGS is size dependent may only be suitable to $\mathrm{m} / \mathrm{z} \sim 1000$. To produce higher molecular weight ions, the softer ionization method of MALDI was used. The tripeptide YYY, which absorbs at $266 \mathrm{~nm}$, was added to the PEG2000/NaCl solution to act as the MALDI matrix. This resulted in particles that produced $[\mathrm{PEG}+\mathrm{Na}]^{+}$ions to $\mathrm{m} / \mathrm{z} \sim 2500$ (Figure $2 \mathrm{~B}$ ). The successful MALDI of these PEG-based particles meant that PEG of differing average molecular weights $>400$ would be useful as standards for online aerosol MALDI-MS. For example, mass spectra were collected from particles that were created from a solution containing multiple PEGs with average molecular weights of 200, 400, 1000, 
and 2000 Da. Both single shot and average mass spectra (Figure 2C) contained a collection of ions spanning a m/z range of $200-2500$ and evenly spaced by $44 \mathrm{~m} / \mathrm{z}$ units. This spectrum exemplifies the dual-purpose use of the YYY as a MALDI matrix and as an internal standard for calibration. By knowing that the one ion that does not fit the PEG pattern of $44 \mathrm{~m} / \mathrm{z}$ unit separations is $[\mathrm{YYY}+\mathrm{H}]^{+}$, the identity of the nearest PEG peak can be determined and thus the entire mass spectrum can be calibrated by choosing a collection of PEG peaks. This approach is useful for preparing external calibrations prior to analysis of peptide-containing aerosols.

The series of low abundance peaks present in Figure $2 \mathrm{C}$ remain unassigned. They do not appear to be adducts of contaminant $\mathrm{K}^{+}$and are more likely doublycationized PEG ions, $\left[\mathrm{PEG}_{\mathrm{n}}+2 \mathrm{Na}\right]^{2+}$, or fragment ions. Factors supporting their assignment as doubly cationized PEG ions include periodic spacing that corresponds to the higher molecular weight PEGs present, the absence of peaks in the highest distribution of PEGs present and the common detection of doubly-cationized polyethers from soft ionization sources. ${ }^{41,53}$

Note that PEG 3350 was also analyzed but resulted in poor signal-to-noise quality. Previous SIMION modeling of our aerosol mass spectrometers has shown that this was due to poor transmission through the reflectron of this instrument. ${ }^{37}$ This limitation in sensitivity of the reflectron instrument has been addressed with the development of a linear TOFMS instrument.

\section{Application to Online Aerosol MS Tuning}

The $\left[\mathrm{PEG}_{\mathrm{n}}+\mathrm{Na}\right]^{+}$peaks from $200-2500 \mathrm{~m} / \mathrm{z}$ in average mass spectra of PEGcontaining particles have resolutions of only 100-200 (M/FWHM). In contrast, a mass spectrum from a single particle has a resolution of $>1000$ (compare Figure $1 \mathrm{~A}$ and 
1D). This is a result of a fundamental difference between fixed-target MALDI mass spectrometers and aerosol mass spectrometers. Each particle in the aerosol beam can be located at any position in the laser beam focus in the ion source, $\sim 400 \mathrm{um}$ in diameter in this case, effectively changing the point source of ionization for each mass spectrum. If unaccounted for, the resultant variability of shot-to-shot mass accuracy reduces the resolution obtained in the mass spectrum of an average of many particles relative to that for a single particle. In fixed target instruments this error is greatly minimized, resulting in superior shot-to-shot mass accuracy.

The poor shot-to-shot reproducibility of aerosol instruments magnifies the challenge of trying to tune an uncalibrated instrument under development. The mass spectra of PEG-containing particles are very easy to recognize on a shot-to-shot basis even if the mass accuracy and resolution are poor. Thus the pattern of peaks separated by $44 \mathrm{~m} / \mathrm{z}$ units facilitates the tuning of aerosol MS instruments. Because a single PEG-containing particle produces ions of similar chemistry over such a wide range of $\mathrm{m} / \mathrm{z}$, aerosol mass spectrometer parameters such as electrode voltages can be optimized without concern for competitive ionization processes complicating the interpretation of ion signals. For instance, the signal suppression effects that occur in mixtures of peptides analyzed by fixed target MALDI-MS ${ }^{35,54}$ have not been studied on a single particle level. As an example, particles containing PEG3350 and DHB were analyzed using the linear TOFMS while varying a single parameter, the delay time prior to switching the guidewire voltage. The guidewire acts as an electrostatic ion guide that increases the transmission efficiency of higher molecular weight ions, i.e. $\mathrm{m} / \mathrm{z}>2000$, by collimating ion trajectories of divergent ions and as a gate to low $\mathrm{m} / \mathrm{z}$ ions. ${ }^{37}$ Figure 3 shows how the PEG ions from single $2.0 \mu \mathrm{m}$ particles can be used to easily visualize improvement in resolution when modifying instrumental 
parameters. For a delay of $2500 \mathrm{~ns}$ a resolution of $\sim 1000$ was achieved at $\mathrm{m} / \mathrm{z} \approx 3600$. Note that this instrument suffers from reduction in resolution similar to that observed for instrument 1 when single particle spectra are averaged. Optimization of the instrumental parameters is still in progress.

\section{A PEG Derivative That Generates Positive and Negative Ion Spectra}

The PEG mass spectra shown so far have focused on the positive ions because PEGs do not generate a corresponding pattern of negative ion signals. However, the characteristics of the positive ion spectra of PEGs are highly desirable for the negative ions as well. It would be ideal to have a single component that would produce both the positive and negative ions to facilitate tuning of both TOF mass analyzers simultaneously. An inherently anionic PEG derivative was expected to satisfy the goal of producing useful negative ion signals. In practice, a commercially available negatively charged end group modified PEG derivative, PEG 4-nonylphenyl-3sulfopropylether (PEG(-)), not only provided easily recognizable negative ion spectra, it also produced positive ions as well (Figure 4). The negative ions in $\mathrm{m} / \mathrm{z}$ range 700 to 1500 correspond with the loss of the nonylphenyl group, $\left[\operatorname{PEG}(-)_{n}-\mathrm{C}_{15} \mathrm{H}_{22}\right]^{-}$. Positive ions were produced by the formation of adducts between the intact negatively charged molecule and two potassium ions, $\left[\mathrm{PEG}(-)_{\mathrm{n}}+2 \mathrm{~K}\right]^{+}$. The formation of these adducts was a result of the high concentration of potassium in the polymer solution provided by the manufacturer. The formation of PEG adducts with two alkali metal ions, $\left[\mathrm{PEG}_{\mathrm{n}}+2 \mathrm{Na}\right]^{2+}$, is commonly observed and reduces the separation of the peaks to $22 \mathrm{~m} / \mathrm{z}$ units because the ions are doubly charged. In contrast, the ions measured here were singly charged because of the anionic nature of the polymer. Thus, the familiar pattern of peaks separated by $44 \mathrm{~m} / \mathrm{z}$ units was maintained. Note that no matrix was required to detect these ions because the polymer itself absorbs the energy of the 
266nm laser. Addition of DHB to the starting solution used to create the particles reduces the abundance of the negative ions with $\mathrm{m} / \mathrm{z}$ between 300 and 800 , suggesting they are fragment ions. The positive ions present in the same $\mathrm{m} / \mathrm{z}$ range may be doubly charged ions, $\left[\mathrm{PEG}(-)_{\mathrm{n}}+3 \mathrm{~K}\right]^{2+}$, or fragment ions. Conclusive assignment is not possible because of their low abundance and instrument resolution. The large number of positive and negative ions produced from single PEG-containing particles provides the opportunity to perform calibrations utilizing a large number of peaks covering a wide $\mathrm{m} / \mathrm{z}$ range. Future work will include investigation of mass accuracy improvements using large numbers of peaks in the calibration, examination of the correlation between positive and negative ion time of flight at high $\mathrm{m} / \mathrm{z}$ on a particleby-particle basis, and study of fundamental ionization mechanisms of single particles.

\section{CONCLUSION}

We have developed a strategy for creating PEG-containing particles that produce an array of reproducible and easily recognizable spectra for aerosol mass spectrometer calibration, including ions of both polarities. This low-cost strategy is currently being employed in the development of our aerosol mass spectrometers and it is envisioned that the same strategies will be useful on any aerosol mass spectrometer platform equipped with a laser desorption ion source.

\section{Acknowledgements}

This work was performed under the auspices of the U.S. Department of Energy by University of California Lawrence Livermore National Laboratory (LLNL) under contract W-7405-ENG-48 and supported by LLNL through laboratory directed research and development grant no. 05-ERD-053. MJB acknowledges a Natural Sciences and Engineering Research Council of Canada (NSERC) Post Doctoral 
Fellowship. EP acknowledges a U.S. Department of Homeland Security (DHS)

Fellowship. UCRL-JRNL-227120.

\section{REFERENCES}

1. Johnston MV, Wexler AS. Anal. Chem. 1995; 67:721A

2. Haefliger OP, Bucheli TD, Zenobi R. Environ. Sci. Tech. 2000; 34:2178

3. Haefliger OP, Bucheli TD, Zenobi R. Environ. Sci. Tech. 2000; 34:2184

4. Angelino S, Suess DT, Prather KA. Environ. Sci. Tech. 2001; 35:3130

5. Noble CA, Prather KA. Mass Spectrom. Rev. 2000; 19:248

6. Gross DS, Galli ME, Silva PJ, Prather KA. Anal. Chem. 2000; 72:416

7. Suess DT, Prather KA. Chem. Rev. 1999; 99:3007

8. Silva PJ, Liu DY, Noble CA, Prather KA. Environ. Sci. Tech. 1999; 33:3068

9. Gard EE, Kleeman MJ, Gross DS, Hughes LS, Allen JO, Morrical BD, Fergenson DP, Dienes T, Galli ME, Johnson RJ, Cass GR, Prather KA. Science 1998; 279:1184

10. Silva PJ, Prather KA. Environ. Sci. Tech. 1997; 31:3074

11. Liu D-Y, Rutherford D, Kinsey M, Prather KA. Anal. Chem. 1997; 69:1808

12. Noble CA, Prather KA. Environ. Sci. Tech. 1996; 30:2667

13. Sinha MP, Platz RM, Friedlander SK, Vilker VL. Int. J. Mass Spectrom. Ion Process. 1984; 57:125

14. Geiray RA, Reilly PTA, Yang M, Whitten WB, Ramsey JM. J. of. Microbiol. Methods 1997; 29:191

15. Stowers MA, Van Wuijckhuijse AL, Marijnissen JCM, Scarlett B, Van Baar BLM, Kientz CE. Rapid Commun. Mass Spectrom. 2000; 14:829

16. Srivastava A, Pitesky ME, Steele PT, Tobias HJ, Fergenson DP, Horn JM, Russell SC, Czerwieniec GA, Lebrilla CB, Gard EE, Frank M. Anal. Chem. 2005; 77:3315

17. Czerwieniec GA, Russell SC, Tobias HJ, Pitesky ME, Fergenson DP, Steele PT, Srivastava A, Horn JM, Frank M, Gard EE, Lebrilla CB. Anal. Chem. 2005; 77:1081

18. Fergenson DP, Pitesky ME, Tobias HJ, Steele PT, Czerwieniec GA, Russell SC, Lebrilla CB, Horn JM, Coffee KR, Srivastava A, Pillai SP, Shih M-TP, Hall HL, Ramponi AJ, Chang JT, Langlois RG, Estacio PL, Hadley RT, Frank M, Gard EE. Anal. Chem. 2004; 76:373

19. Steele PT, Tobias HJ, Fergenson DP, Pitesky ME, Horn JM, Czerwieniec GA, Russell SC, Lebrilla CB, Gard EE, Frank M. Anal. Chem. 2003; 75:5480

20. van Wuijckhuijse AL, Stowers MA, Kleefsman WA, van Baar BLM, Kientz CE, Marijnissen JCM. J. Aerosol Sci. 2005; 36:677

21. Tobias HJ, Schafer MP, Pitesky M, Fergenson D, Horn J, Frank M, Gard EE. Appl. Environ. Microbiol. 2005; 71:6086

22. Nash DG, Baer T, Johnston MV. Int. J. Mass Spectrom. 2006; 258:2

23. Jackson SN, Mishra S, Murray KK. Rapid Commun. Mass Spectrom. 2004; 18:2041

24. Murray KK, Russell DH. Anal. Chem. 1993; 65:2534

25. Murray KK, Russell DH. J. Amer. Soc. Mass Spectrom. 1994; 5:1 
26. Fei X, Wei G, Murray KK. Anal. Chem. 1996; 68:1143

27. Mansoori BA, Johnston MV, Wexler AS. Anal. Chem. 1996; 68:3595

28. He L, Murray KK. J. Mass Spectrom. 1999; 34:909

29. Russell SC, Czerwieniec GA, Lebrilla CB, Steele PT, Riot V, Coffee KR, Frank M, Gard EE. Anal. Chem. 2005; 77:4734

30. Li L, Golding RE, Whittal RM. J. Amer. Chem. Soc. 1996; 118:11662

31. Onnerfjord P, Nilsson J, Wallman L, Laurell T, Marko-Varga G. Anal. Chem. 1998; 70:4755

32. Ekstrom S, Ericsson D, Onnerfjord P, Bengtsson M, Nilsson J, Marko-Varga G, Laurell T. Anal. Chem. 2001; 73:214

33. Keller BO, Li L. J. Amer. Soc. Mass Spectrom. 2001; 12:1055

34. Bogan MJ, Agnes GR. Anal. Chem. 2002; 74:489

35. Sjodhal J, Kempka M, Hermansson K, Thorsen A, Roeraade J. Anal. Chem. 2005; 77:827

36. Steele PT, Srivastava A, Pitesky ME, Fergenson DP, Tobias HJ, Gard EE, Frank M. Anal. Chem. 2005; 77:7448

37. Czerwieniec GA, Russell SC, Lebrilla CB, Coffee KR, Riot V, Steele PT, Frank M, Gard EE. J. Amer. Soc. Mass Spectrom. 2005; 16:1866

38. Russell SC, Czerwieniec GA, Lebrilla CB, Tobias HJ, Fergenson DP, Steele PT, Pitesky ME, Horn JM, Srivastava A, Frank M, Gard EE. J. Amer. Soc. Mass Spectrom. 2004; 15:900

39. Bogan MJ, Srivastava A, Tobias HJ, Martin S, Steele PT, McJimpsey E, Coffee KR, Fergenson DP, Gard EE, Lebrilla CB, Frank M. 53rd American Society for Mass Spectrometry Conference on Mass Spectrometry and Allied Topics June 59, 2005;San Antonio, TX

40. Hoteling AJ, Kawaoka K, Goodberlet MC, Wan-Mo Y, Owens KG. Rapid Commun. Mass Spectrom. 2003; 17:1671

41. Bogan MJ, Agnes GR. J. Amer. Soc. Mass Spectrom. 2002; 13:177

42. Gidden J, Wyttenbach T, Jackson AT, Scrivens JH, Bowers MT. J. Amer. Chem. Soc. 2000; 122:4692

43. Wyttenbach T, Von Heldon G, Bowers MT. Int. J. Mass Spectrom. Ion Process. 1997; 165/166:377

44. Nohmi T, Fenn JB. J. Am. Chem. Soc 1992; 114:3241

45. Wong SF, Meng CK, Fenn JB. J. Phys. Chem. 1988; 92:546

46. Mattern DE, Hercules DM. Anal. Chem. 1985; 57:2041

47. Fei X, Murray KK. Anal. Chem. 1996; 68:3555

48. Kéki S, Szilágyi LS, Deák G, Zsuga M. J. Mass Spectrom. 2002; 37:1074

49. Zenobi R, Knochenmuss R. Mass Spectrom. Rev. 1998; 17:337

50. Knochenmuss R, Stortelder A, Breuker K, Zenobi R. J. Mass Spectrom. 2000; 35: 1237

51. Knochenmuss R, Zenobi R. Chem. Rev. 2002; 1032:441

52. Lehmann E, Knochenmuss R, Zenobi R. Rapid Commun. Mass Spectrom. 1997; 11:1483

53. Kéki S, Nagy L, Deák G, Zsuga M. J. Amer. Soc. Mass Spectrom. 2005; 16:152

54. Kratzer R, Eckerskorn C, Karas M, Lottspeich F. Electrophoresis 1998; 19:1910 


\section{List of Figures}


Figure 1. Average mass spectra (instrument 1) of 200 particles created from solutions containing $1 \mathrm{mM}$ PEG 400 and (A) $1 \mathrm{mM} \mathrm{NaCl}$, (B) $1 \mathrm{mM} \mathrm{KCl}$, or (C) $1 \mathrm{mM}$ each $\mathrm{NaCl}$ and $\mathrm{KCl}$. PEG adduct ions in (A) and (B) are labeled with PEG degree of polymerization, $n$. The dashed guidelines facilitate direct comparison of $\mathrm{Na}^{+}$versus $\mathrm{K}^{+}$adducts. (D) A mass spectrum from a single $1.0 \mu \mathrm{m}$ diameter particle that contributed to the average spectrum in $(\mathrm{A})$. 

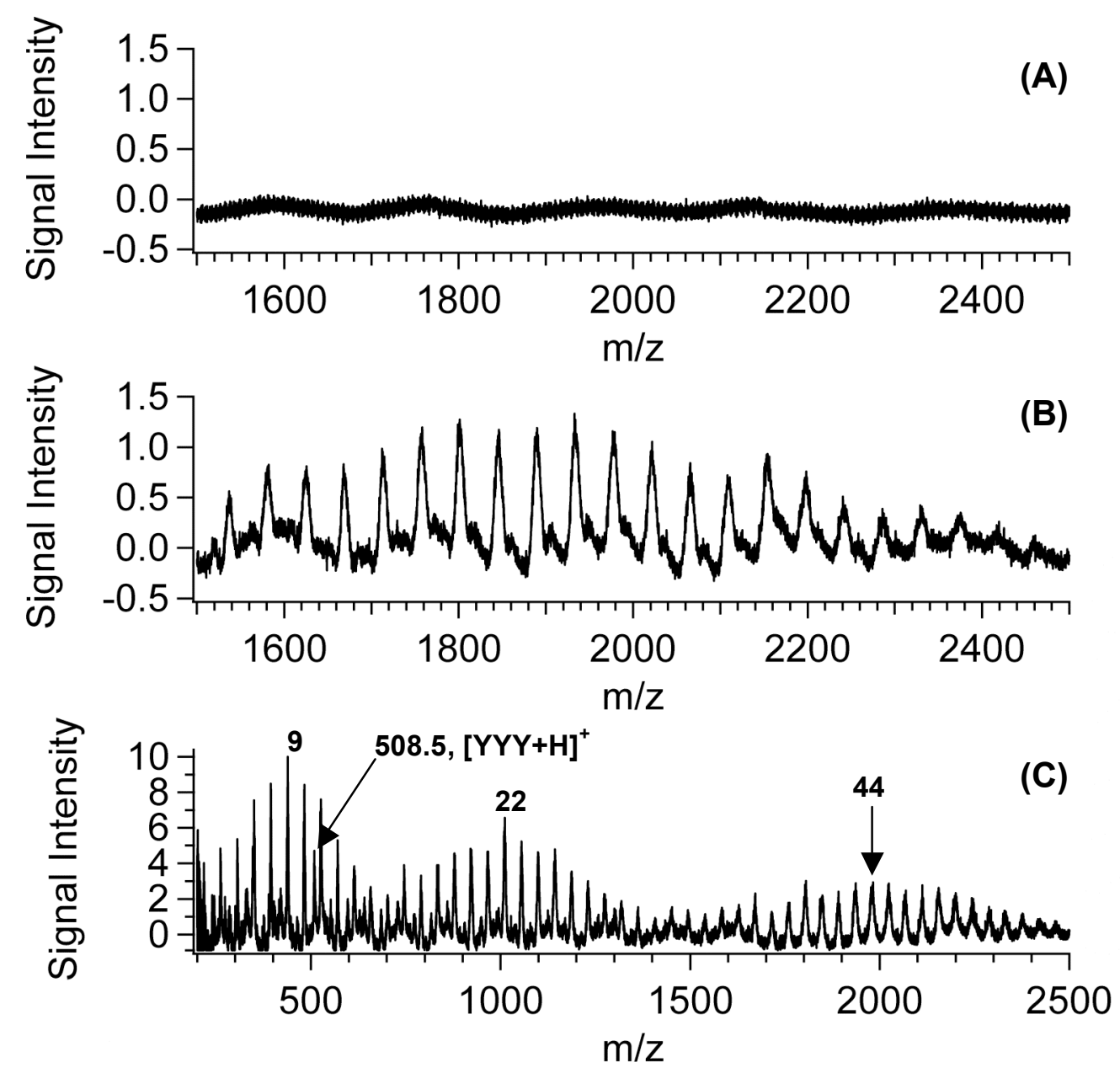

Figure 2. Average mass spectra (instrument 1) collected from $>500$ particles created by nebulizing a $1 \mathrm{mM}$ PEG 2000 solution containing (A) pure water and (B) $1 \mathrm{mM}$ YYY in water. (C) Average mass spectrum of 2000 particles created from a solution containing $1 \mathrm{mM}$ each of PEGs 200, 400, 1000, 2000 and the peptide YYY. The degree of polymerization, $n$, is labeled on several of the PEG ions ( $\mathrm{Na}^{+}$adducts). 


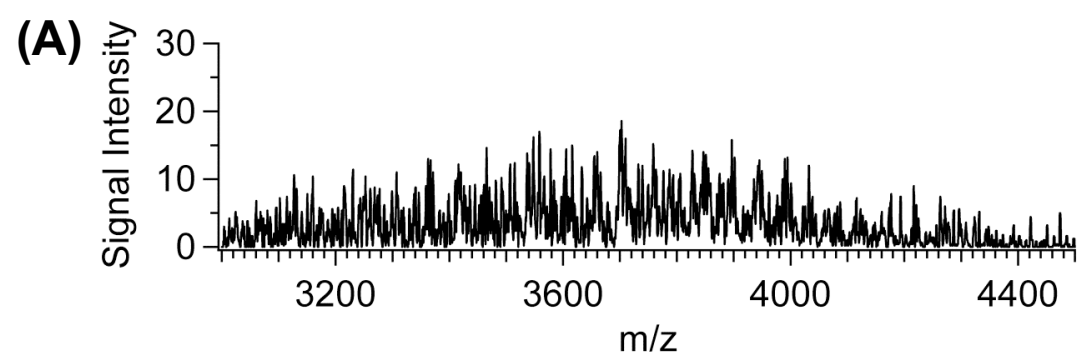

(B) $\underset{\frac{\pi}{\omega}}{2} 30$

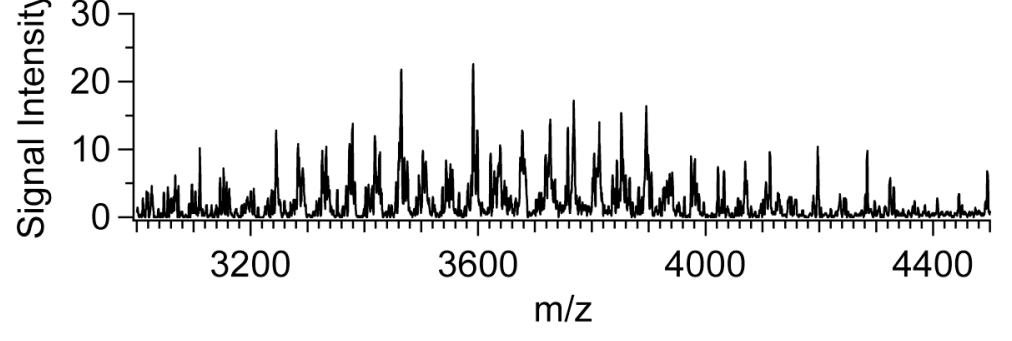

(C) 30
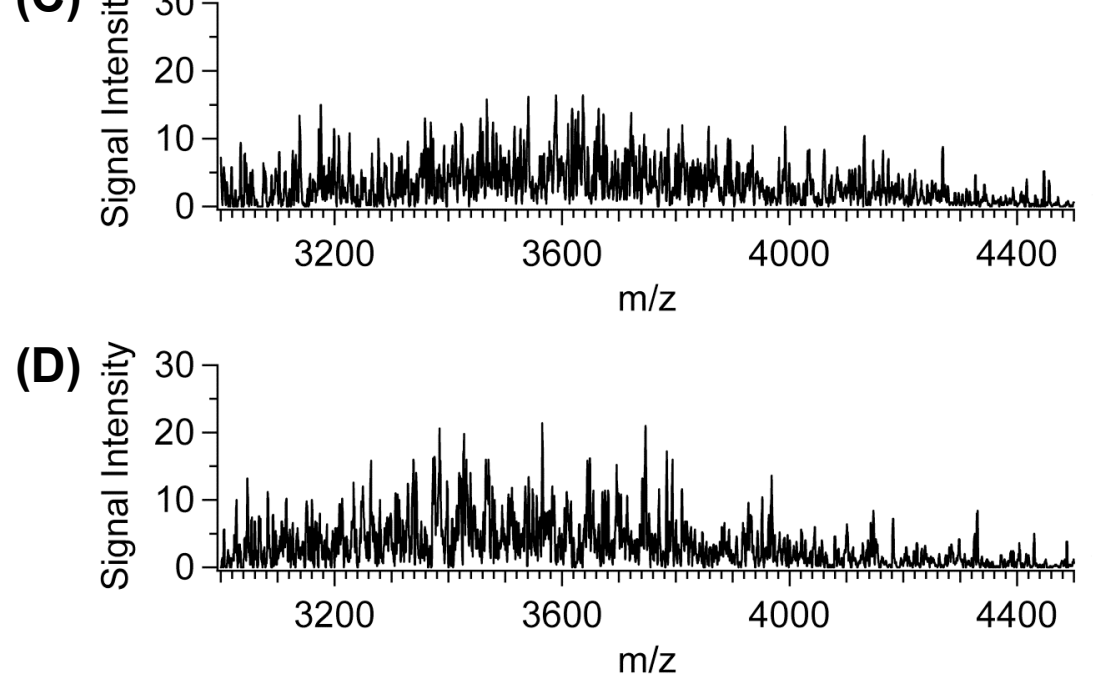

Figure 3. Tuning the linear bioaerosol mass spectrometer (instrument 2) resolution using particles containing PEG 3350 and DHB. Single shot mass spectra collected with a delay time between the desorption/ionization pulse and switching on the guidewire voltage of (A) $250 \mathrm{~ns}$, (B) $2500 \mathrm{~ns}$, (C) 4000 ns, and (D) $5000 \mathrm{~ns}$. 


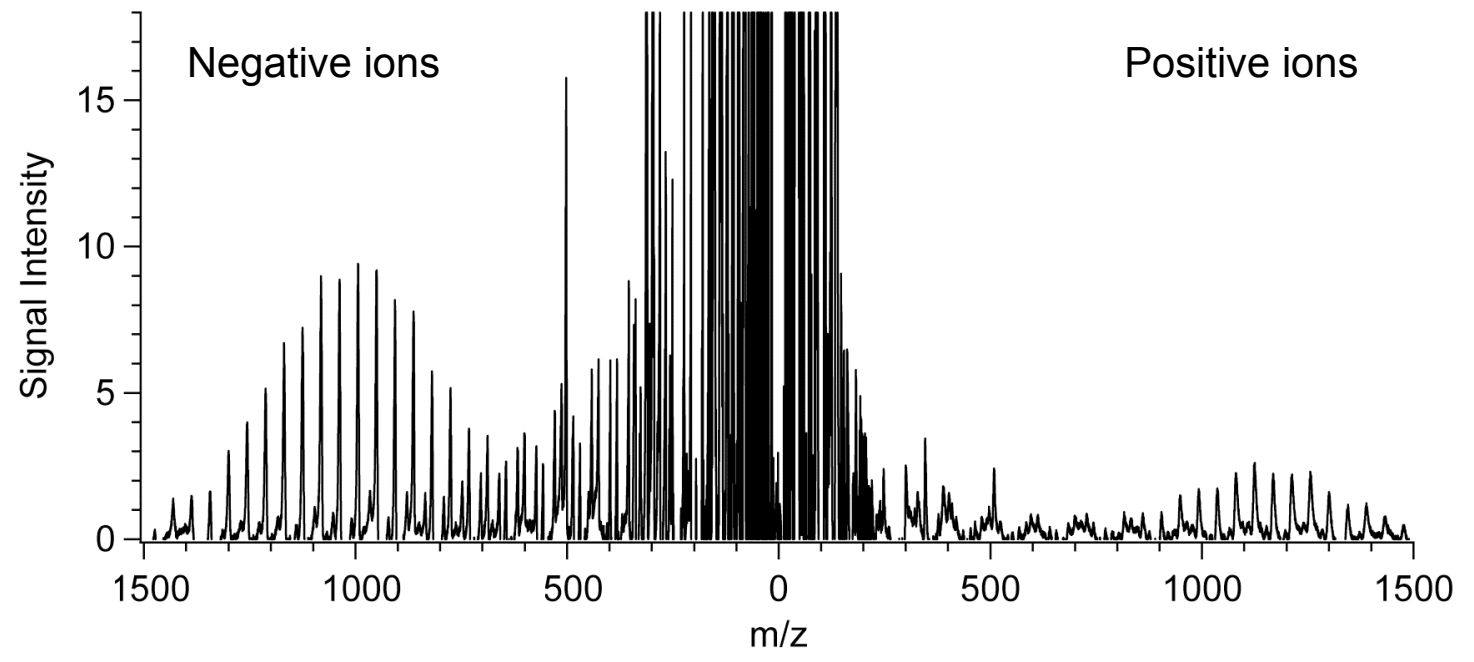

Figure 4. Positive and negative ion average mass spectra of 200 particles prepared from a $1 \mathrm{mM}$ solution of PEG(-), collected on instrument 1. 